\title{
Treatment of Ischial Pressure Sores with Both Profunda Femoris Artery Perforator Flaps and Muscle Flaps
}

\author{
Chae Min Kim, In Sik Yun, Dong Won Lee, Dae Hyun Lew, Dong Kyun Rah, Won Jai Lee \\ Department of Plastic and Reconstructive Surgery, Institute for Human Tissue Restoration, Severance Hospital, Yonsei University College of \\ Medicine, Seoul, Korea
}

Background Reconstruction of ischial pressure sore defects is challenging due to extensive bursas and high recurrence rates. In this study, we simultaneously applied a muscle flap that covered the exposed ischium and large bursa with sufficient muscular volume and a profunda femoris artery perforator fasciocutaneous flap for the management of ischial pressure sores. Methods We retrospectively analyzed data from 14 patients (16 ischial sores) whose ischial defects had been reconstructed using both a profunda femoris artery perforator flap and a muscle flap between January 2006 and February 2014. We compared patient characteristics, operative procedure, and clinical course.

Results All flaps survived the entire follow-up period. Seven patients (50\%) had a history of surgery at the site of the ischial pressure sore. The mean age of the patients included was 52.8 years (range, 18-85 years). The mean follow-up period was 27.9 months (range, 3-57 months). In two patients, a biceps femoris muscle flap was used, while a gracilis muscle flap was used in the remaining patients. In four cases (25\%), wound dehiscence occurred, but healed without further complication after resuturing. Additionally, congestion occurred in one case (6\%), but resolved with conservative treatment. Among 16 cases, there was only one $(6 \%)$ recurrence at 34 months.

Conclusions The combination of a profunda femoris artery perforator fasciocutaneous flap and muscle flap for the treatment of ischial pressure sores provided pliability, adequate bulkiness and few long-term complications. Therefore, this may be used as an alternative treatment method for ischial pressure sores.

Keywords Pressure ulcer / Ischium / Perforator flap / Muscle
Correspondence: Won Jai Lee Department of Plastic and Reconstructive Surgery, Severance Hospital, Yonsei University Medical College, 50-1 Yonsei-ro,

Seodaemun-gu, Seoul 120-752, Korea

Tel: +82-2-2228-2219

Fax: +82-2-82-2-393-6947

E-mail: pswjlee@yuhs.ac

Received: 29 Apr 2014 • Revised: 19 May 2014 • Accepted: 30 May 2014

pISSN: 2234-6163・elSSN: 2234-6171・http://dx.doi.org/10.5999/aps.2014.41.4.387・ Arch Plast Surg 2014;41:387-393

The authors would like to thank DongSu Jang, MFA, (Medical Illustrator, Seoul, Korea) for his help with the illustrations.

No potential conflict of interest relevant to this article was reported.

\section{INTRODUCTION}

Pressure sores result from the destruction of skin and underlying tissue due to continuous pressure applied to the skin and muscle. As a result, the blood supply to the tissue is decreased, which leads to necrosis. Additionally, pressure sores are influenced by patient position, patient movement, nutrition, and the general health status of the patient [1]. Ischial pressure sores are the most common type of sores to occur in the wheelchairbound patient, and there is always a risk of recurrence despite 
successful treatment [2]. There are several studies that have examined long-term outcomes including recurrence rates in patients with pressure sores [3-6]. Ischial pressure sores specifically have a widely variable recurrence rate of $7 \%$ to $48 \%[4,5]$. This variability indicates that it would be difficult to estimate a single factor that influences recurrence, and that this typically occurs in relation to postoperative care and rehabilitation status [6]. The flaps used for reconstruction of ischial pressure sores have included inferior gluteus maximus flaps, V-Y hamstring myocutaneous flaps, gluteal thigh flaps, gracilis myocutaneous flaps, adipofascial turnover and fasciocutaneous flaps, biceps femoris musculocutaneous flaps, tensor fascia lata flaps, inferior gluteal artery perforator (IGAP) flaps [7], lateral thigh fasciocutaneous flaps, anterior thigh flaps, rectus abdominis myocutaneous flaps, and adductor muscle perforator flaps.

After the concept of a perforator flap was introduced by Koshima et al. [8], the superior gluteal artery perforator flap (SGAP) and IGAP became more frequently used in the treatment of these sores $[7,9]$. Perforator flaps have become more popular due to advantages such as sparing of the underlying muscle with resultant decreased donor-site morbidity, as well as the possibility of improving aesthetic outcomes. Based on perforasome theory, a flap can be based on any perforator, whether free or pedicled.

The profunda femoris artery (deep femoral artery) has four perforating arteries after the branching of the medial and lateral circumflex arteries $[10,11]$. Among these, the first and second perforating arteries have cutaneous branches that travel to the posteromedial aspect of the thigh $[10,12]$. Therefore, these branches could be used in the reconstruction of ischial pressure sores. There have been few reports, however, of using profunda femoris artery perforator flaps for ischial pressure sores $[13,14]$.

The advantages of using muscle flaps in the surgical treatment of pressure sores are as follows: 1) bulk to eliminate dead space, 2) reliable blood supply, 3 ) mass of tissue that allows for better distribution of pressure, and 4) superior infection control [15]. In particular, musculocutaneous flaps are useful for filling dead space in large, deep wounds, while fasciocutaneous flaps may have insufficient volume to accomplish this. Additionally, because of their abundant flow, musculocutaneous flaps are a good choice for treatment of infected wounds [16].

In our study, we used a unilateral gracilis or biceps muscle flap along with a profunda femoris artery perforator fasciocutaneous flap for treatment of ischial defects with large bursas. The muscle flap was used as a turnover flap to cover the ischial bone and to provide volume to fill the dead space. The profunda femoris artery perforator fasciocutaneous flap was used to cover the surface of the defect, and for dual padding of the ischium. This du- al-flap technique is a durable and efficient reconstructive option for major ischial defects due to recurrent ischial pressure sores with minimal donor site morbidity.

\section{METHODS}

Between January 2006 and February 2014, 14 patients (16 ischial sores) who were surgically treated using both a profunda femoris artery perforator flap and a muscle flap for ischial pressure sores were included in this study. Among these patients, 11 were men (13 sores) and three were women (three sores). We compared and analyzed the size of defect, treatment method, rate of recurrence, and whether or not it was treated after a previous complication based on patient medical records.

\section{Surgical technique}

Each patient was placed in the prone position. After meticulous debridement and softening of the ischial bony prominent portion, ostectomy or rasping was performed. The profunda femoris artery perforator was mapped using portable Doppler flowmetry (Fig. 1). After securing a skin flap with sufficient size and length, we identified the location of the profunda femoris artery perforator on the ipsilateral medial side along the gluteal fold at the ischial tuberosity. The skin flap was constructed according to the distance to the defect and the available range of transposition (Fig. 1A). To fill the dead space and cover the exposed ischium, a muscle flap constructed from the gracilis or biceps femoris muscle was used. An incision was made from the superiolateal margin of the flap, which was carried down to include the fascia, extending to the medial knee in an S-shape pattern. Using subfascial dissection, 1-4 musculocutaneous perforators were identified and clipped to allow for maximal arch of transposition of the flap (Fig. 2). The fasciocutaneous flap, which was based on the profunda femoris artery perforator, was then elevated. To allow for greater flap mobility, the tissue around the pedicle was further dissected without full skeletonization of the perforator pedicle (Fig. 2B). The gracilis or biceps muscle under the previously elevated skin flap was then detached from its insertion site and dissected proximally until the main pedicle was identified (Fig. 1B). The muscle was then transposed to the exposed ischial site in a turn-over pattern. The elevated profunda femoris artery perforator flap was advanced or transpositioned toward the defect (Fig. 1C). The flap was inserted without tension, and the donor defect was closed primarily with minimal subcutaneous undermining, which was achieved with adduction of the thighs (Fig. 1D). The duration of pedicle dissection and flap elevation was around 30 minutes and the duration of the total surgery was around 3 to 4 hours. Two negative suction drainage catheters 


\section{Fig. 1. Diagram showing the surgical steps for harvesting the profunda femoris artery perforator flap and gracilis muscle flap}

(A) Preoperative design. We identified and marked the location of the perforator preoperatively. (B) After performing ostectomy at the bony prominence, we rotated the gracilis muscle to fill the dead space. (C) We covered the skin defect by performing transposition of the profunda femoris artery perforator (*) flap. (D) Postoperative image.
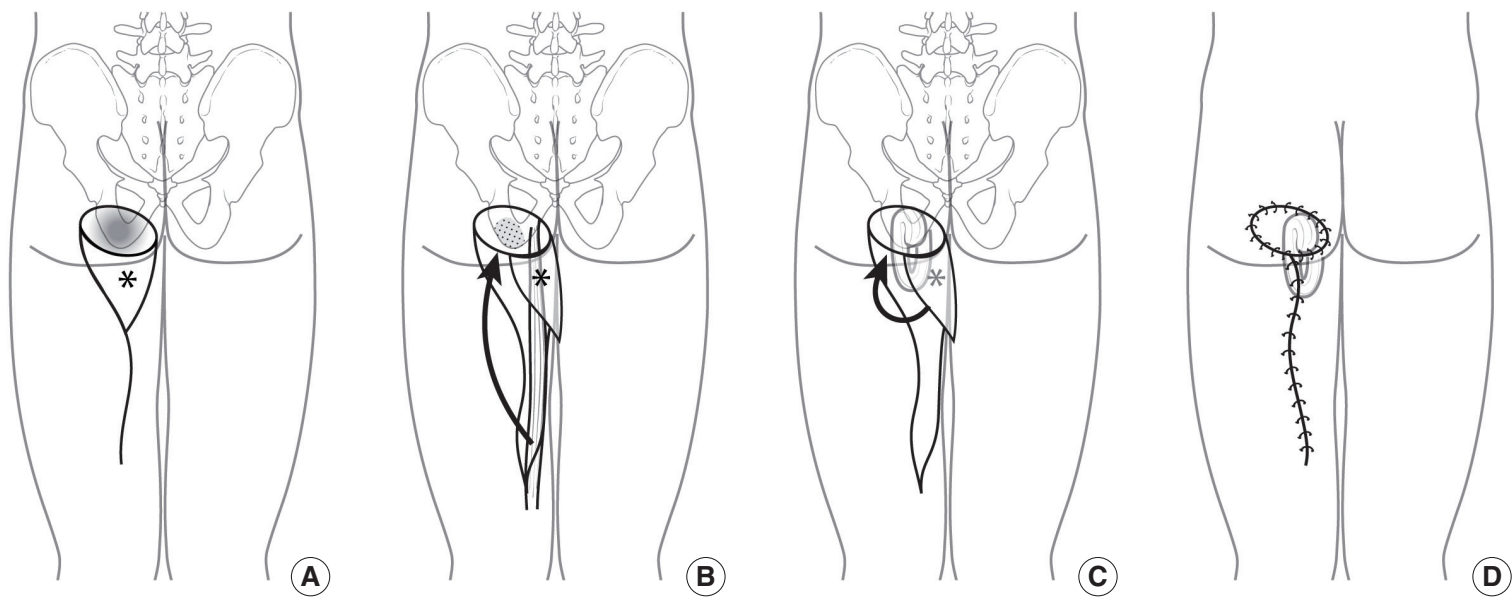

\section{Fig. 2. Profunda femoris artery perforator-based fasciocutaneous flap}

(A) Schematic vascular diagram of profunda femoris artery perforator $\left(^{*}\right)$ flap. (B) This is an intraoperative image of Profunda femoris artery perforator flap and gracilis flap after dissection and before transposition. The yellow round dotted line is where the perforator is thought to be located. The existence of perforator was checked by an intraoperative Doppler flowmetry and perforator skeletonization was not performed because there was no problem in the transposition of the flap.
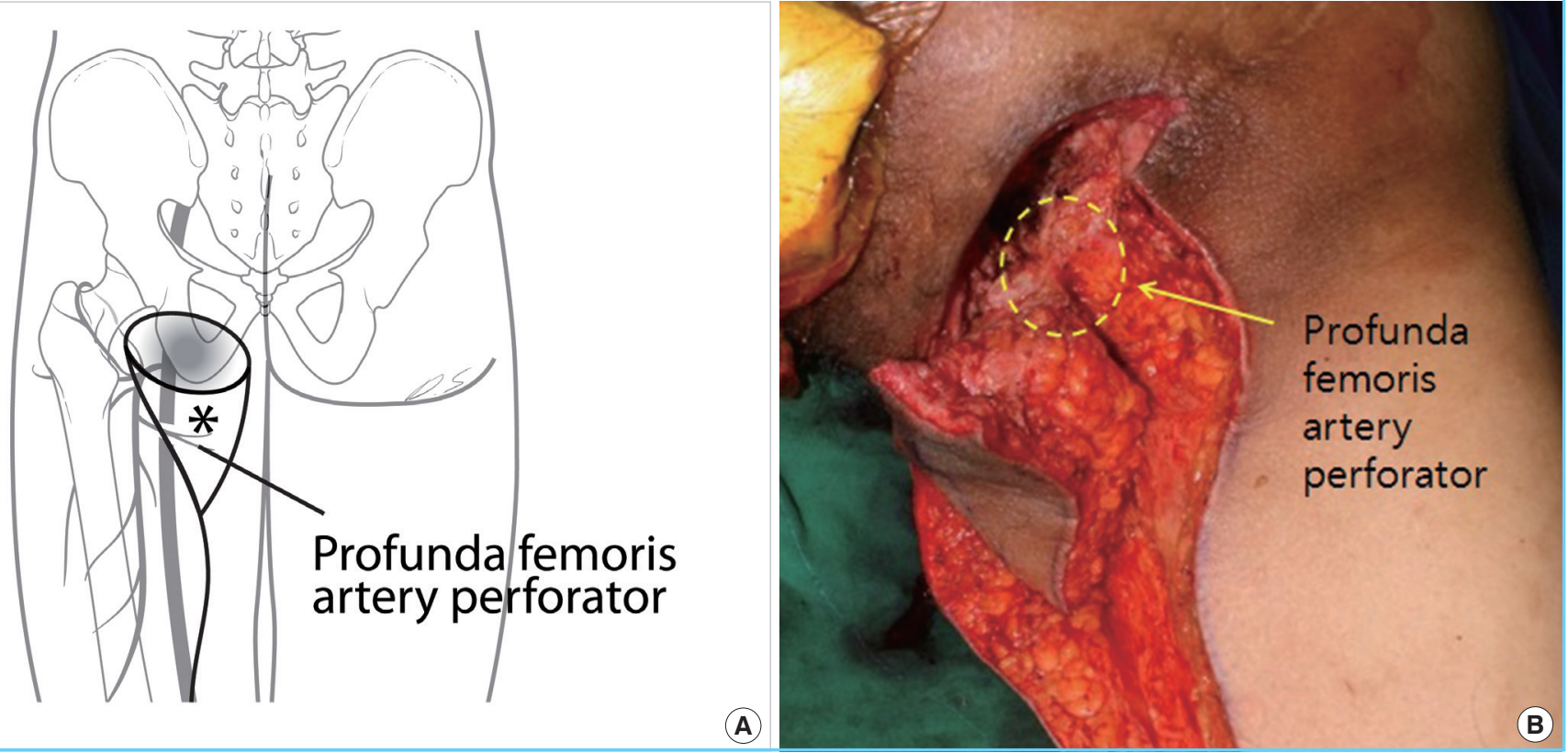

were placed for at least seven days, and the patients remained in the prone position for two weeks to limit pressure on the flap.

\section{RESULTS}

Seven $(50 \%)$ patients had a history of surgery at the same site as the ischial pressure sore (Table 1). The mean age of the patients was 52.8 years (range, $18-85$ years). The majority of the patients were paraplegic (13 cases, $81 \%)$, two were quadriplegic $(12.5 \%)$, and one was ambulatory $(6 \%)$. Fourteen patients had suffered spinal cord injury due to trauma, one patient had spinal stenosis, and one patient had been diagnosed with a spinal cord tumor. Among 16 cases (14 patients), the mean follow-up period was 27.9 months (range, 3-57 months). The size of the flap 
Table 1. Characteristics of patients (patient information)

\begin{tabular}{|c|c|c|c|c|c|c|c|c|c|c|c|c|c|c|c|c|c|}
\hline No. & Sex & $\begin{array}{l}\text { Age } \\
\text { (yr) }\end{array}$ & Dx & Site & $\begin{array}{l}\text { Defect } \\
\text { size }(\mathrm{cm})\end{array}$ & $\begin{array}{l}\text { Flap size } \\
(\mathrm{cm})\end{array}$ & $\begin{array}{c}\text { Bursa } \\
\text { size }(\mathrm{cm})\end{array}$ & $\begin{array}{l}\text { Muscle } \\
\text { flap }\end{array}$ & $\begin{array}{l}\text { Predisposing } \\
\text { factor }\end{array}$ & Status & $\begin{array}{c}\text { Operation } \\
\text { Hx. }\end{array}$ & $\mathrm{PHx}$ & $\begin{array}{c}\text { Short } \\
\text { term Cx }\end{array}$ & $\mathrm{Tx}$ & $\begin{array}{l}\text { Long } \\
\text { term Cx }\end{array}$ & Tx & $\begin{array}{l}\text { Follow-up } \\
\text { (mo) }\end{array}$ \\
\hline 1 & $\mathrm{~F}$ & 85 & Ischial sore & Lt & $3 \times 2$ & $8 \times 4$ & $5 \times 4$ & Gracilis & Spinal stenosis & Ambulation & - & Dementia & $x$ & $x$ & $x$ & $x$ & 18 \\
\hline 2 & M & 52 & $\begin{array}{l}\text { Ischial sore } \\
\text { (recurred) }\end{array}$ & Lt & $3 \times 3$ & $8 \times 5$ & $6 \times 4$ & Gracilis & T12-L1 Fx & Paraplegia & $\begin{array}{l}\text { Sore operation } \\
\text { once }\end{array}$ & $x$ & $x$ & $x$ & $x$ & $x$ & 3 \\
\hline 3 & M & 52 & Ischial sore & Lt & $4 \times 4$ & $10 \times 6$ & $8 \times 6$ & Gracilis & C5-6 Fx & Quadriplegia & - & $\begin{array}{l}\text { CRF, } \\
\text { Schizo }\end{array}$ & $\begin{array}{l}\text { Wound } \\
\text { dehiscence }\end{array}$ & Revision & $x$ & $x$ & 29 \\
\hline 4 & M & 39 & Ischial sore & $\begin{array}{l}\mathrm{Lt} \\
\mathrm{Rt}\end{array}$ & $\begin{array}{l}5 \times 2 \\
2 \times 2\end{array}$ & $\begin{array}{l}6 \times 4 \\
3 \times 3\end{array}$ & $\begin{array}{l}5 \times 4 \\
3 \times 3\end{array}$ & $\begin{array}{c}\text { Gracilis } \\
x\end{array}$ & $\begin{array}{l}\text { Spinal cord } \\
\text { tumor mets }\end{array}$ & Paraplegia & - & $\begin{array}{l}\text { Brain } \\
\text { tumor }\end{array}$ & $\begin{array}{l}x \\
x\end{array}$ & $\begin{array}{l}x \\
x\end{array}$ & $\begin{array}{l}x \\
x\end{array}$ & $\begin{array}{l}x \\
x\end{array}$ & $\begin{array}{l}14 \\
-\end{array}$ \\
\hline 5 & M & 63 & $\begin{array}{l}\text { Ischial sore } \\
\text { (recurred) }\end{array}$ & $\mathrm{Lt}$ & $2 \times 1$ & $12 \times 5$ & $6 \times 3$ & Gracilis & $\mathrm{SCl}$ & Paraplegia & $\begin{array}{l}\text { Sore operation } \\
\text { once }\end{array}$ & $x$ & $x$ & $x$ & $x$ & $x$ & 25 \\
\hline 6 & M & 33 & $\begin{array}{l}\text { Ischial sore } \\
\text { (recurred) }\end{array}$ & Lt & $2 \times 2$ & $11 \times 6$ & $7 \times 4$ & Gracilis & L2 Fx & Paraplegia & $\begin{array}{l}\text { Sore operation } \\
\text { twice }\end{array}$ & $\mathrm{x}$ & $\begin{array}{l}\text { Wound } \\
\text { dehiscence }\end{array}$ & Revision & $x$ & $x$ & 56 \\
\hline 7 & M & 54 & $\begin{array}{l}\text { Ischial sore } \\
\text { (recurred) }\end{array}$ & Rt & $1 \times 1$ & $10 \times 5$ & $4 \times 4$ & Gracilis & T11 Fx & Paraplegia & $\begin{array}{l}\text { Sore operation } \\
\text { several times }\end{array}$ & HTN, CVA & $x$ & $x$ & $x$ & $x$ & 3 \\
\hline 8 & M & 72 & $\begin{array}{l}\text { Ischial sore } \\
\text { (recurred) }\end{array}$ & Lt & $2 \times 2$ & $5 \times 3$ & $7 \times 4$ & Gracilis & $\mathrm{SCl}$ & Paraplegia & $\begin{array}{l}\text { Sore operation } \\
\text { several times }\end{array}$ & DM & $\begin{array}{l}\text { Wound } \\
\text { dehiscence }\end{array}$ & Revision & $x$ & $x$ & 21 \\
\hline 9 & M & 39 & Ischial sore & $\begin{array}{l}\text { Rt } \\
\mathrm{Lt}\end{array}$ & $\begin{array}{l}4 \times 3 \\
3 \times 3\end{array}$ & $\begin{array}{l}8 \times 5 \\
9 \times 5\end{array}$ & $\begin{array}{r}9 \times 6 \\
12 \times 6\end{array}$ & $\begin{array}{l}\text { Gracilis } \\
\text { Gracilis }\end{array}$ & T4-5 Fx & Paraplegia & $\begin{array}{l}\text { Sore operation } \\
\text { several times }\end{array}$ & $x$ & x & $x$ & $\begin{array}{l}\text { Rt recur } \\
\quad \text { after } 34 \mathrm{~m}\end{array}$ & IGAP & $\begin{array}{l}57 \\
31\end{array}$ \\
\hline 10 & M & 72 & $\begin{array}{l}\text { Ischial sore } \\
\text { (recurred) } \\
\text { Ischial sore }\end{array}$ & $\begin{array}{l}\mathrm{Rt} \\
\mathrm{Lt}\end{array}$ & $\begin{array}{l}3 \times 3 \\
2 \times 2\end{array}$ & $\begin{array}{r}7 \times 4 \\
10 \times 6\end{array}$ & $\begin{array}{l}5 \times 4 \\
4 \times 4\end{array}$ & $\begin{array}{l}\text { Biceps } \\
\text { femoris } \\
\text { Gracilis }\end{array}$ & T10 SCl & Paraplegia & $\begin{array}{l}\text { Sore operation } \\
\text { once }\end{array}$ & COPD & $\begin{array}{c}\mathrm{x} \\
\text { Wound } \\
\text { dehiscence }\end{array}$ & $\begin{array}{c}x \\
\text { Revision }\end{array}$ & $\begin{array}{l}x \\
x\end{array}$ & $\begin{array}{l}x \\
x\end{array}$ & $\begin{array}{r}27 \\
4\end{array}$ \\
\hline 11 & M & 36 & Ischial sore & Rt & $3 \times 2$ & $7 \times 5$ & $5 \times 3$ & Gracilis & C-SCl & Quadriplegia & - & $x$ & x & $x$ & $x$ & $x$ & 57 \\
\hline 12 & $\mathrm{~F}$ & 46 & $\begin{array}{l}\text { Ischial sore } \\
\text { (recurred) }\end{array}$ & Lt & $8 \times 5$ & $12 \times 6$ & $12 \times 4$ & Gracilis & L1-3 SCl & Paraplegia & $\begin{array}{l}\text { Sore operation } \\
\text { several times }\end{array}$ & $x$ & $\begin{array}{l}\text { Flap } \\
\text { congestion }\end{array}$ & $\begin{array}{l}\text { Conservative } \\
\text { care }\end{array}$ & $x$ & $x$ & 24 \\
\hline 13 & $\mathrm{~F}$ & 18 & Ischial sore & Lt & $3 \times 3$ & $7 \times 4$ & $7 \times 4$ & $\begin{array}{c}\text { Biceps } \\
\text { femoris }\end{array}$ & $\mathrm{T} 6 \mathrm{SCl}$ & Paraplegia & - & Scoliosis & x & $x$ & $x$ & $x$ & 45 \\
\hline 14 & M & 78 & Ischial sore & $\mathrm{Lt}$ & $2 \times 2$ & $7 \times 5$ & $8 \times 5$ & Gracilis & $\mathrm{SCl}$ & Paraplegia & - & HTN & $x$ & $x$ & $x$ & $x$ & 32 \\
\hline
\end{tabular}

The mean follow-up period was 27.9 months for 14 patients with ischial pressure sores (16 sores).

Dx, diagnosis; Hx., history; PHx, past history; Cx, complication; Tx, treatment; Lt, left; Rt, right; SCl, spinal cord injury; HTN, hypertension; CVA, cerebrovascular accident; DM, diabetes mellitus; IGAP, inferior gluteal artery perforator flap; COPD, chronic obstructive pulmonary disease.

was variable, from $3 \times 3 \mathrm{~cm}$ to $12 \times 6 \mathrm{~cm}$, and most of the flaps healed without complications. The size of the pressure sores ranged from $1 \times 1 \mathrm{~cm}$ to $8 \times 5 \mathrm{~cm}$, though the size of the bursa was typically several times larger than that of the skin defect. The size of the bursa was estimated by measuring the diameter using a cotton swab prior to surgery. In four cases $(25 \%)$, wound dehiscence occurred but completely healed after resuturing. In one case (6\%), congestion occurred, but improved with conservative treatment. During long-term follow-up, only one case (6\%) recurred after 34 months and was treated with an IGAP flap. In seven patients (50\%) who had a history of surgery at the same site of the ischial pressure sore, surgery that was performed with the technique described yielded good results without complications for a mean follow-up period of 22.7 months.

\section{Case 1 (patient no. 1 )}

An 85-year-old female patient with spinal stenosis presented with a left ischial pressure sore, and underwent surgical reconstruction with a profunda femoris artery perforator flap and gracilis muscle flap (Fig. 3). Preoperative findings included a skin defect measuring $3 \times 2 \mathrm{~cm}$ and a bursa measuring $8 \times 4 \mathrm{~cm}$. We decreased the defect size using vaccum assisted closure therapy (VAC) for two weeks prior to surgery. There was a coexisting sacral pressure sore, which was treated with a SGAP flap.
Postoperative follow-up for 18 months revealed no evidence of recurrence or complications.

\section{Case 2 (patient no. 6)}

A 33-year-old patient with paraplegia due to 10th thoracic vertebra injury sustained in a traffic accident presented with a left ischial pressure sore that was treated with primary sutures twice at another hospital three years and six months before an IGAP flap was performed three years ago. The pressure sore recurred at the site of the IGAP flap, and was reconstructed with a profunda femoris artery perforator flap and gracilis muscle flap (Fig. 4). Preoperative findings included a skin defect measuring $2 \times 2$ $\mathrm{cm}$ and a bursa measuring $11 \times 6 \mathrm{~cm}$. On postoperative day 10 , a $2 \mathrm{~cm}$ open wound was noted at the surgical site, which healed without further complication after resuturing. Postoperative follow-up was conducted for 56 months without recurrence or complications.

\section{Case 3 (patient no. 9)}

A 39-year-old patient with paraplegia due to fourth thoracic vertebra injury sustained in a traffic accident presented with a right ischial pressure sore. The dead space was filled using the gracilis muscle, and transposition was performed using a profunda femoris artery perforator flap (Fig. 5). Preoperative findings includ- 


\section{Fig. 3. A case of unilateral ischial pressure sore (case 1)}

(A) The bursa is deeper and wider than the skin defect. (B) The dead space was filled with the gracilis muscle and covered with the elevated profunda femoris artery perforator flap. (C) Postoperative photo 18 months after reconstruction.
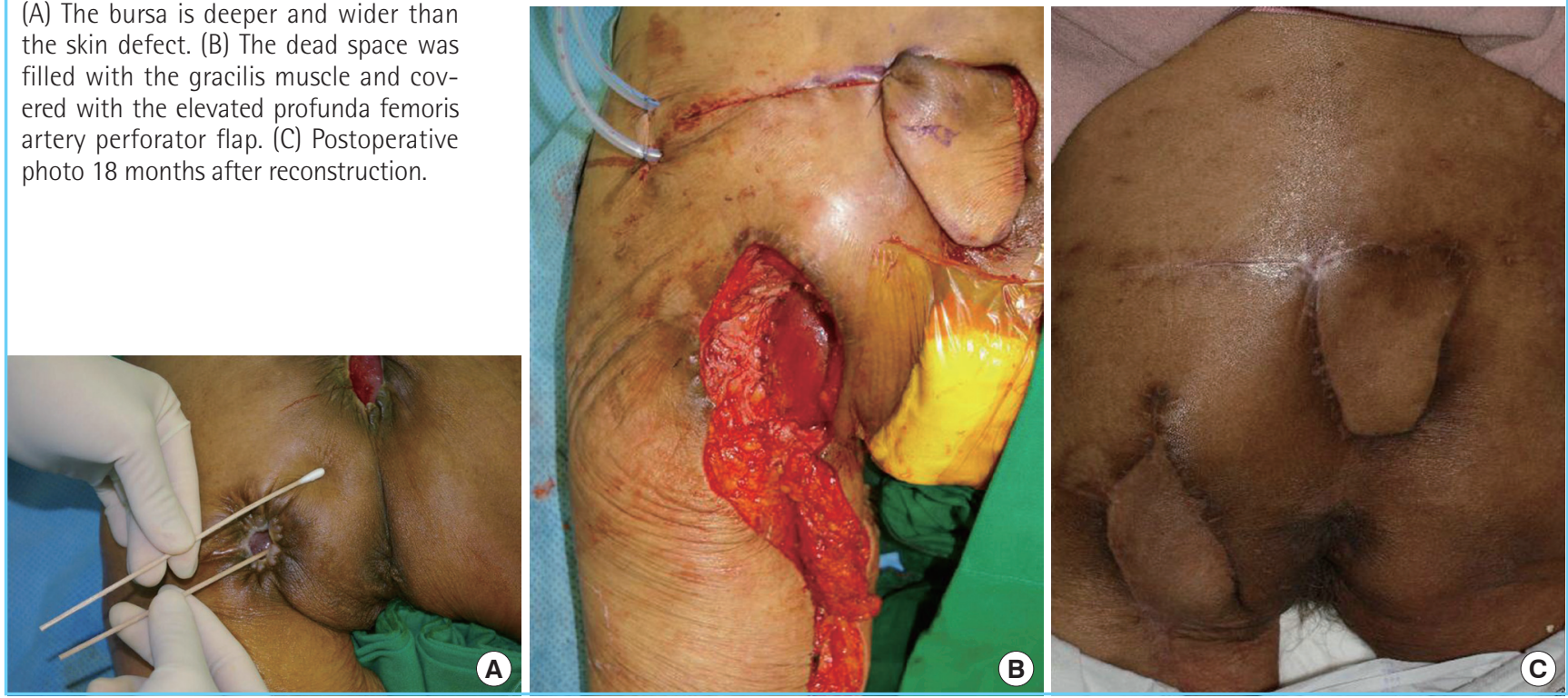

\section{Fig. 4. Picture showing the surgical steps (case 2)}

(A) The perforator was identified and marked preoperatively, and was rechecked after debridement. (B) Elevation of the profunda femoris artery perforator fasciocutaneous flap and gracilis muscle flap. The dead space was filled with the rotated gracilis muscle. (C) Defect coverage was achieved by transposition of the profunda femoris artery perforator flap. (D) Follow-up image at 12 months.
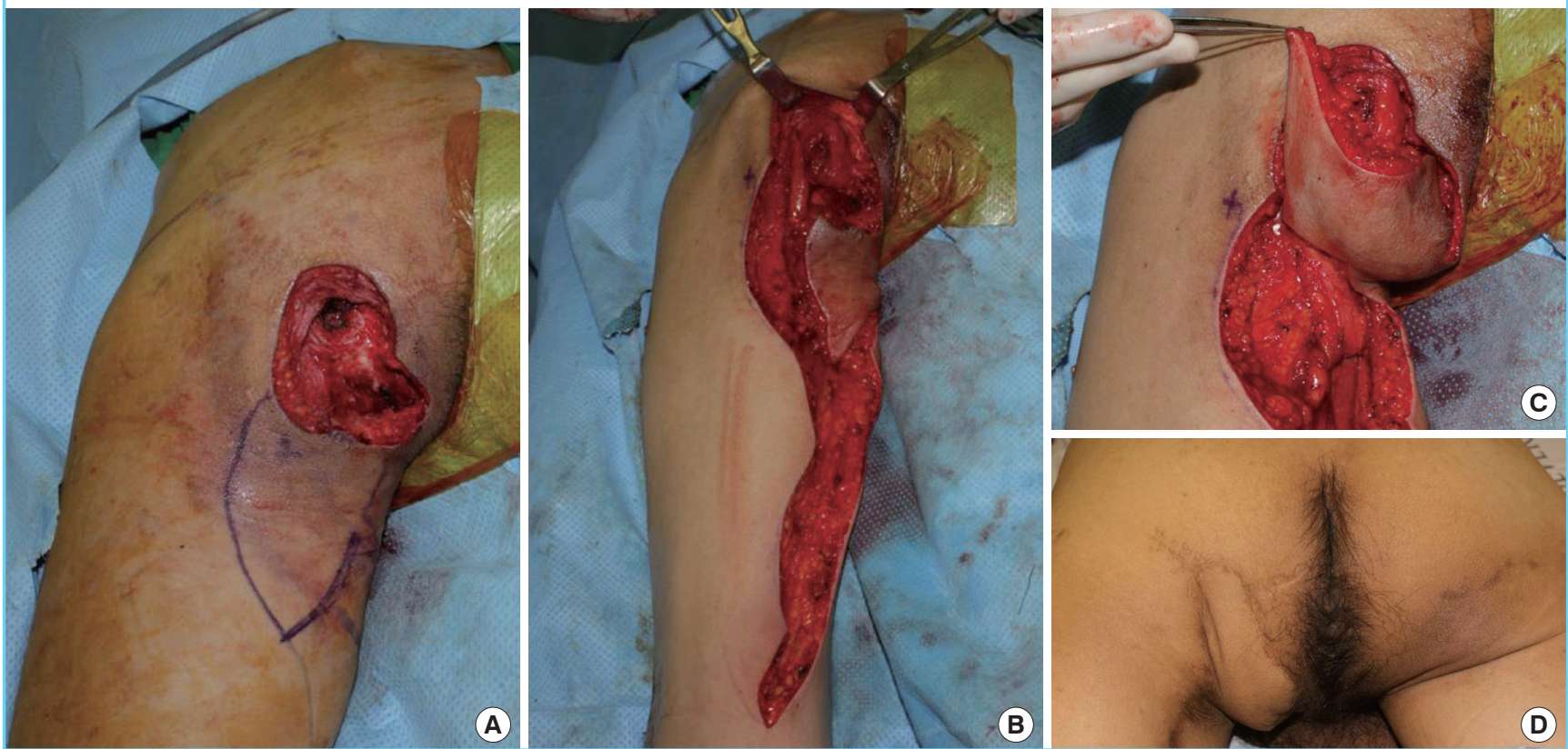

B)

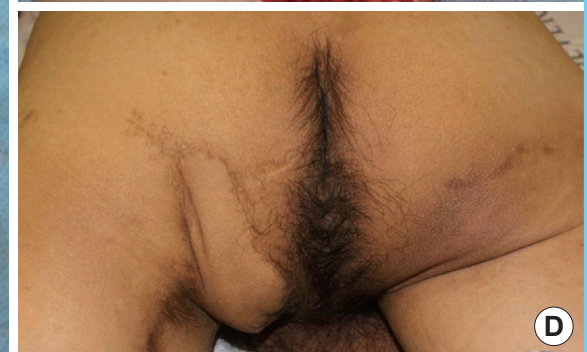

ed a skin defect measuring $4 \times 3 \mathrm{~cm}$ and a bursa measuring $8 \times 5$ $\mathrm{cm}$. After one year, a left ischial pressure sore developed, and was reconstructed using a gracilis muscle flap and a profunda femoris artery perforator island flap. The skin defect was $3 \times 3$ $\mathrm{cm}$ in size, and the bursa measured $9 \times 5 \mathrm{~cm}$. The right ischial pressure sore recurred 34 months after surgery due to dead space, and was treated with bursa resection and IGAP flap.

\section{DISCUSSION}

Ischial pressure sores most frequently occur in wheelchairbound patients. Despite successful surgery, however, recurrence and complications frequently occur making this condition difficult to treat. Moreover, paralyzed patients also tend to have pressure sores in the sacral or trochanteric regions. Thus several flap surgeries are often needed. For this reason, preservation of the 
Fig. 5. A case of bilateral ischial pressure sore (case 3)

(A) This patient had bilateral ischial pressure sores. A right ischial pressure sore was reconsturcted using a gracilis muscle flap and a profunda femoris artery perforator island flap. After one year, a left ischial pressure sore also occurred and was subsequently reconstructed same method. (B) Follow-up image 18 months after right ischial pressure sore reconstruction.
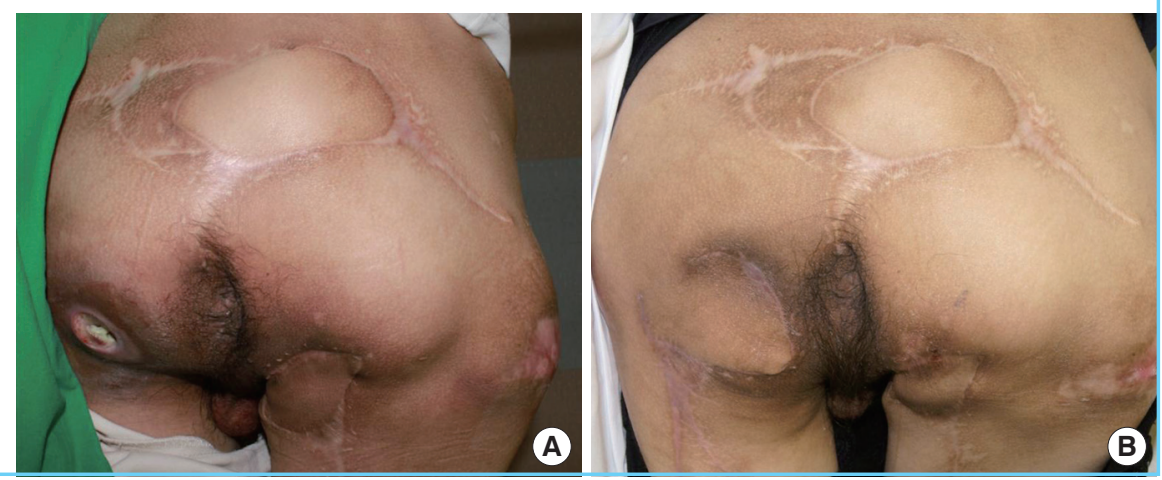

tissue structure and vascularity and is important in cases in which secondary surgery is required [17].

Various surgical methods have been introduced for the treatment of ischial pressure sores. Recently, the use of perforators has become more popular based on anatomical and clinical studies. The perforators that can be used for ischial pressure sore defects are largely divided into those in the gluteal regions and those in the thigh regions. Unal et al. [18] divided the origins of the perforators into two groups depending on the available donor flap site: 1) IGA and perforators of the descending branch of the IGA, and 2) posterior thigh vessels (medial or lateral circumflex femoral artery, profunda femoris artery).

Each pedicle includes either the IGAP in the gluteal region, or the profunda femoris artery, medial, or lateral femoral circumflex artery perforators in the thigh region. Among these, the IGAPs distributed in the gluteal region have been frequently used in reconstructive surgery for ischial pressure sores after Higgins et al. [7] reported a case in which the IGAP was successfully used $[18,19]$.

In a case in which the posterior thigh perforator was used in 1983, Baek [20] described the use of the skin territory of the third perforator of the profunda femoris as well their methods of elevation. Since then, Homma et al. [13] performed reconstruction of ischial pressure sores using the posterior thigh perforator. In that study, good results were achieved in 11 patients with ischial pressure sores using a posteromedial thigh fasciocutaneous flap based on perforators from the gracilis or adductor magnus muscle. The adductor magnus muscle perforator that was described has been confirmed to be a profunda femoris artery perforator by anatomical and imaging studies $[14,21,22]$. Angrigiani et al. $[11,14]$ subsequently identified the location of the profunda femoris artery perforator and elevated the posterolateral thigh flap and posteromedial thigh flap for treatment of ischial pressure sores. Lee et al. [2] reported good results using a $\mathrm{V}-\mathrm{Y}$ profunda femoris artery perforator flap and gracilis muscle flap in the treatment of ischial pressure sores. We used a similar method, but dissected the pedicle of the V-Y advancement flap further, elevated the fasciocutaneous flap, and performed transposition. By using this method, we allowed for coverage of the large skin defect that resulted from debridement of the necrotic skin and reduced the tension at the ischial site.

We used a muscle flap together with a profunda femoris artery perforator flap in all patients. This was because pressure sores typically have a larger bursa than other skin defects. We used a gracilis muscle flap in 14 cases and a biceps femoris muscle flap in two cases. The gracilis muscle is commonly used in the reconstruction of ischial pressure sores because it is easily accessible and has sufficient vascularity [23]. Two patients were treated using a biceps femoris muscle flap because this muscle was more easily accessed than the gracilis, and it was adequate for filling the dead space. In addition, we were able to simultaneously elevate the profunda femoris artery perforator flap and muscle flap with the patient in the prone position, unlike Lee et al. [2] who elevated the gracilis in the supine position first, and then applied the profunda femoris artery perforator flap.

In 14 patients ( 16 total cases) we had a mean follow-up period of 27.9 months, and one case of recurrence at 34 months after surgery. The remaining patients had no further problems at the surgical site during a mean follow-up period of more than two years. Our study demonstrates that simultaneous use of a profunda femoris artery perforator flap and a muscle flap results in good durability, and may be a feasible option for the treatment of ischial pressure sores. Additionally, it would be helpful for patients who will likely require multiple surgeries to avoid damaging the pedicles and their vascular supply by being aware of the location and anatomical structure of each perforator [24]. The patients preserved all of their gluteal skin and pedicle, so in case of recurrence they could be used.

The pre-existing inferior gluteal myocutaneous flap is one of the most commonly used method in ischial pressure sore [16] 
and this conventional method has also shows good results [25]. But the method in this journal uses muscle flap in cases of recurrence or large defects, which has advantages in bone padding or dead space filling. And in primary cases, when there is recurrence the convential method can be used again, so it has advantages when choosing a reconstruction method.

In conclusion, use of both a profunda femoris artery perforator flap and muscle flap for the treatment of ischial pressure sores resulted in good durability and few long-term complications. Thus, this may be a useful method for reconstruction of ischial pressure sores.

\section{REFERENCES}

1. Bass MJ, Phillips LG. Pressure sores. Curr Probl Surg 2007; 44:101-43.

2. Lee SS, Huang SH, Chen MC, et al. Management of recurrent ischial pressure sore with gracilis muscle flap and V-Y profunda femoris artery perforator-based flap. J Plast Reconstr Aesthet Surg 2009;62:1339-46.

3. Keys KA, Daniali LN, Warner KJ, et al. Multivariate predictors of failure after flap coverage of pressure ulcers. Plast Reconstr Surg 2010;125:1725-34.

4. Hentz VR. Management of pressure sores in a specialty center. A reappraisal. Plast Reconstr Surg 1979;64:683-91.

5. Tavakoli K, Rutkowski S, Cope C, et al. Recurrence rates of ischial sores in para- and tetraplegics treated with hamstring flaps: an 8-year study. Br J Plast Surg 1999;52:476-9.

6. Kierney PC, Engrav LH, Isik FF, et al. Results of 268 pressure sores in 158 patients managed jointly by plastic surgery and rehabilitation medicine. Plast Reconstr Surg 1998;102: 765-72.

7. Higgins JP, Orlando GS, Blondeel PN. Ischial pressure sore reconstruction using an inferior gluteal artery perforator (IGAP) flap. Br J Plast Surg 2002;55:83-5.

8. Koshima I, Moriguchi T, Soeda S, et al. The gluteal perforator-based flap for repair of sacral pressure sores. Plast Reconstr Surg 1993;91:678-83.

9. Coskunfirat OK, Ozgentas HE. Gluteal perforator flaps for coverage of pressure sores at various locations. Plast Reconstr Surg 2004;113:2012-7.

10. Ahmadzadeh R, Bergeron L, Tang M, et al. The posterior thigh perforator flap or profunda femoris artery perforator flap. Plast Reconstr Surg 2007;119:194-200.

11. Angrigiani C, Grilli D, Siebert J, et al. A new musculocutaneous island flap from the distal thigh for recurrent ischial and perineal pressure sores. Plast Reconstr Surg 1995;96:935-40.

12. Saad A, Sadeghi A, Allen RJ. The anatomic basis of the profunda femoris artery perforator flap: a new option for autologous breast reconstruction--a cadaveric and computer tomography angiogram study. J Reconstr Microsurg 2012;28: 381-6.

13. Homma K, Murakami G, Fujioka H, et al. Treatment of ischial pressure ulcers with a posteromedial thigh fasciocutaneous flap. Plast Reconstr Surg 2001;108:1990-6.

14. Angrigiani C, Grilli D, Thorne CH. The adductor flap: a new method for transferring posterior and medial thigh skin. Plast Reconstr Surg 2001;107:1725-31.

15. Thiessen FE, Andrades P, Blondeel PN, et al. Flap surgery for pressure sores: should the underlying muscle be transferred or not? J Plast Reconstr Aesthet Surg 2011;64:84-90.

16. Cushing CA, Phillips LG. Evidence-based medicine: pressure sores. Plast Reconstr Surg 2013;132:1720-32.

17. Lin PY, Kuo YR, Tsai YT. A reusable perforator-preserving gluteal artery-based rotation fasciocutaneous flap for pressure sore reconstruction. Microsurgery 2012;32:189-95.

18. Unal C, Ozdemir J, Yirmibesoglu O, et al. Use of inferior gluteal artery and posterior thigh perforators in management of ischial pressure sores with limited donor sites for flap coverage. Ann Plast Surg 2012;69:67-72.

19. Kim YS, Lew DH, Roh TS, et al. Inferior gluteal artery perforator flap: a viable alternative for ischial pressure sores. J Plast Reconstr Aesthet Surg 2009;62:1347-54.

20. Baek SM. Two new cutaneous free flaps: the medial and lateral thigh flaps. Plast Reconstr Surg 1983;71:354-65.

21. Hurwitz ZM, Montilla R, Dunn RM, et al. Adductor magnus perforator flap revisited: an anatomical review and clinical applications. Ann Plast Surg 2011;66:438-43.

22. Hallock GG. The propeller flap version of the adductor muscle perforator flap for coverage of ischial or trochanteric pressure sores. Ann Plast Surg 2006;56:540-2.

23. Labandter HP. The gracilis muscle flap and musculocutaneous flap in the repair of perineal and ischial defects. Br J Plast Surg 1980;33:95-8.

24. Wong CH, Tan BK, Song C. The perforator-sparing buttock rotation flap for coverage of pressure sores. Plast Reconstr Surg 2007;119:1259-66.

25. Sameem M, Au M, Wood T, et al. A systematic review of complication and recurrence rates of musculocutaneous, fasciocutaneous, and perforator-based flaps for treatment of pressure sores. Plast Reconstr Surg 2012;130:67e-77e. 